\title{
Audit Team Characteristics, and External Environment Audit Factors: Effects on Audit Quality in Libya
}

\author{
Fuad Elmahedi Hussein $^{1 *}$, Mustafa Mohd Hanefah ${ }^{2}$ and Khaled Ali Endaya ${ }^{3}$ \\ ${ }^{1}$ Faculty of Economics and Political Sciences, Azzaytuna University, Libya \\ ${ }^{2}$ Faculty of Economics and Muamalat, Universiti Sains Islam Malaysia \\ ${ }^{3}$ Faculty of Economics and Trade, Azzaytuna University, Tarhuna, Libya
}

Article History
Received: 19.05 .2020
Accepted: 17.06 .2020
Published: 14.10 .2020
Journal homepage:
https://www.easpublisher.com/easjebm
Quick Response Code

\begin{abstract}
Purpose: The paper aims to analyse audit team characteristics that were perceived to be affected on audit quality. Specifically, it focuses principally on whether audit team characteristics, i.e., independence, continuous education and training, experience and professional conduct enhances audit quality. This study examines the moderating effect of the external environment audit i.e., professional bodies, laws and regulations, and recognized standards in the relationship between audit team characteristics and audit quality. Design/methodology/approach: Multiple regression analysis is applied to examine the association between variables of the study. A questionnaire survey was conducted of 251 external auditors, by personally administered questionnaire from Libyan the Association of Accountants and Auditors (LAAA) . Findings: the audit team characteristics have positively and significantly related to audit quality. As well as the regression analysis at dimension level shows positively and significantly related to audit quality. The findings also indicate that the external environment audit factors moderates the relationship between variables of study. Practical implications: The instrument presented will provide to measure audit quality in Libya, with a practical understanding in the area of audit quality. Moreover, researchers and practitioners from other may be able to use these models in future to measure audit quality. Originality/value: This is the first study examining the impact of external environmental factors on audit quality and the findings demonstrated its moderating effect on audit quality.
\end{abstract}

Keywords: Audit team characteristics, External environment audit factors, Audit quality, Libya.

Copyright (C) 2020 The Author(s): This is an open-access article distributed under the terms of the Creative Commons Attribution 4.0 International License (CC BY-NC 4.0) which permits unrestricted use, distribution, and reproduction in any medium for non-commercial use provided the original author and source are credited.

\section{INTRODUCTION}

The auditing profession has faced increasing pressure from external parties to monitor and enhance audit quality process the auditing profession's ability to meet these pressures is hampered because of lack of an objective means by which to evaluate audit quality [1]. Grant, et al. [2] revealed that the quality of auditing remains an issue of concern in the auditing profession, the government, the investors, and stakeholders as a whole. Reisch [3] argued that new audit quality researches continue to emerge owing to the constant changes in the auditing profession. Until now, there is no consensus between audit bodies about its definition or a universally accepted measuring technique [4]. This study investigates the impact of external environment audit on the relationship between audit team characteristics and audit quality. The following sections provide the literature review and hypotheses development, methodology, variable measurement and testing goodness of data, followed by empirical results, discussion of findings and conclusion.

\section{Literature review and hypotheses development}

This paper examines the relationship among audit team characteristics, external environment and audit quality. This section displays the hypotheses of study based on the literature and the arguments provided by this paper.

\section{Audit team characteristics}

The definition of the auditor's team possesses psychological power that influences auditor's behavior while audit quality is viewed to be a function of auditor performance [5]. The human capital has become a key driver of auditor quality and the investments in it as the educational attainment of auditors, their work experience, professional certification, and continuing professional development which can improve auditor quality $[6,7]$. The professional conduct and auditor's ability are considered as major factors affecting performance auditors [8]. Wooten [9] suggest that audit team factors were more important than firm-wide factors in determining audit quality. 
Auditor independence is considered the hallmark and the cornerstone of auditing profession and also is viewed as the very important factor in business sector in protecting the interest of several parties from stakeholders [10-14]. Audit quality has positive correlation with audit independence, so high-quality auditors give better quality and greater reliability to financial reports, if the auditor does have full independence $[15,16]$. The Sarbanes-Oxley Act of 2002 (SOX) strengthened auditor independence by proposing three mechanisms to improve auditor's independence: in section $(201,207,301)$. According to IFAC (2010) ISQC 1 of which sections (21-25) are mandated particularly for independence requirements.

Continuous professional education and training are one of the primary pillars ensuring that competent authorities and rehabilitation meet the requirements necessary to perform the audit function and to achieve audit quality. Deis and Giroux [17] point out that according to Meinhardt et al., the educational attainment of auditors can help refine the quality of audits and they said that the educational level is associated positively with audit quality. Shoommuangpak [18] find that continuous learning is significantly and positively associated with audit quality. Cheng et al. [7] further argue that the audit firm needs to continue to attract, develop, educate, and train auditors at all levels to perform high quality audits. Explain standard No. (IES 7) (2006) by IAESB, the kinds of learning activities constitute continuous professional development of professional auditors.

Experience allows seasoned auditors to perform tasks superior to auditors having low experience. This is consistent with prior studies on experience [19, 20, 21, 18]. Given the intense focus on the increasing complexity of accounting and auditing rules, it is imperative for external auditors to possess very specific skills. Bedard [22] indicates that knowledge and skills are acquired through education and years of audit experience. Shoommuangpak [18] indicate that, auditor's experience is of great important and it impacts audit quality.

At present, most lawsuits against auditing firms allege unethical behavior on the part of auditors, and public trust in the auditing profession is at a steady decline [23]. The fundamental principle of professional behavior imposes a commitment on all auditors to comply with relevant laws and regulations and to avoid any work that may discredit the profession and avoidance of any behavior that might bring discredit to auditors' action [24]. The International Ethics Standards Board for Accountants (IESBA), issued a revised code of ethics for auditors (2009) in paragraph 100.5 which states that an auditor shall comply with the relevant ethical requirements, section 150.1 states that; the auditor's adherence to the principles of professional conduct is mandatory, section 150.2 also regards marketing and promoting themselves and their action.

Based on the foregoing discussion, most of the studies dedicated to the measurement of audit quality have dealt with a single or two variables. Carcello et al., [25] mentioned that one variable cannot examine the audit quality factor of one in isolation from all other factors. DeFond [26] suggested that the factors should be combined as a better measure of audit quality. In order to get a high quality, the auditor must be independent and this is only possible to obtain the scientific and professional certificates and continuous training and sufficient experience and adhere to the rules of professional conduct. As a result of this integration between the characteristics of the audit team has been assembled in one group according to suggested DeFond.

H1: There is a positive relationship between audit team characteristics and audit quality.

H1a: Each dimension of audit team characteristics i.e., independence, continuous education and training, experience and professional conduct and development is positively related to audit quality.

\section{The external environment audit factors}

There is a need to highlight the external environment audit factors aiding external auditors in strengthening audit quality. Professional bodies have contributed, nationally or internationally, in the regulation and supervision of the auditing profession. A few studies considered the importance of professional bodies [1, 27]. Grant, et al. [2] provide evidence that professional bodies can achieve more than mere restriction of login and monopolization of the auditing function; they can improve audit quality through the provision of economical and effective regulations using monitoring and imposing sanctions on violators.

Laws, regulations and directives issued from the legislative authority in the country, or through professional bodies, which regulates the profession, are legally binding. These laws and regulations have strongly affected the practice of the audit profession. Several studies noted the overall importance of laws and regulations [28-32. The auditor's knowledge of laws and regulations facilitates the avoidance of punishment and leads to promotion of audit quality.

The quality is the most fundamental characteristic of international auditing standards [33]. Some studies note the importance of recognized standards [25, 27, 32]. At the same time, external environmental factors have an impact on the audit team characteristics. 
H2: External environment audit factors moderates the relationship among audit team, and audit quality.
H2a: Each dimension of external environment audit factors i.e. professional bodies, laws and regulations, and recognized standards, moderates the relationship between audit team characteristics and audit quality.

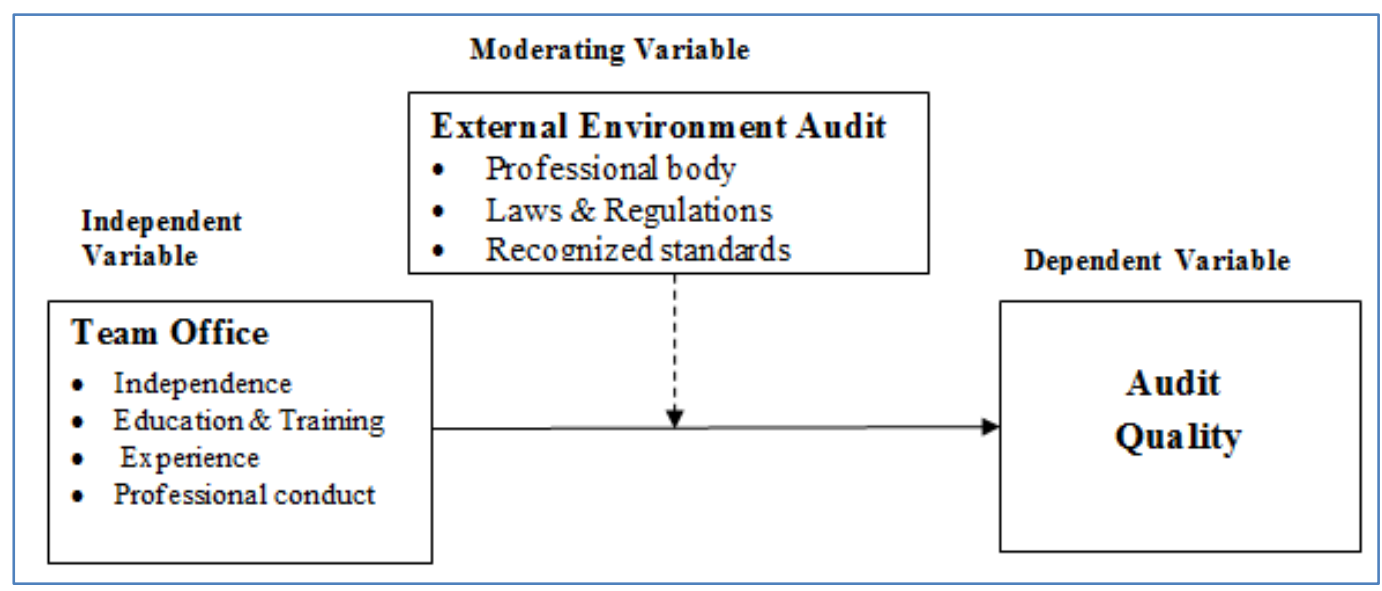

\section{Methodology \\ POPULATION SAMPING THE STUDY}

Libyan Association of Accountants and Auditors (LAAA) is the population of this study. LAAA is the regulatory body of the accounting profession in Libya which was established by the Libyan government Law No. 116/1973. The paragraph 23 of Law was limited to those practicing the profession is a member of LAAA, as well as paragraph 24 of the law was to be restricted to citizens of Libya. The total number of the population that collected in August 2012 was 1206.

The sample size obtained for the study was appropriate according to the rules of proposed by Roscoe (1975, cited in Sekaran, 34]), whereby sample size larger than 30 and less than 500 are appropriate and the sample size should be several times (preferably 10 times or more) as large as the number of variables in multivariate study. Therefore, 530 LAAA's members in Tripoli and Benghazi where $85 \%$ of the Libyan audit offices are located [35] were selected randomly from the reality of record LAAA based on the LAAA membership register in August 2012 as sample of the study.

\section{Data Collection}

The data were used personally administered questionnaire. Personally administered questionnaires are the best data collection method when the survey is limited to: (a) a local area; (b) the researcher wishes to target specific groups of people; or (c) wishes to have respondents answer questions at their work place [34]. From 530 Libyan external auditors, 288 returned the questionnaire. However, 14 questionnaires were returned blank and 4 respondents answered incompletely more than one page. Also, 17 were excluded from the study by outliers' analysis. Only 251 questionnaires are finally useable for the study resulting in a response rate of $47.37 \%$. Although Sawan [36] found that the response rate for the external auditors amounted to $52 \%$, but the current study's response rate is considered satisfactory when compared to other study Khorwatt [37] reported a response rate of $41 \%$.

Table 1 displays details of the respondents' profiles according to the occupation, academic qualification, experience as auditor, and size of audit office.

Table-1: Respondents Profile

\begin{tabular}{|r|c|c|}
\hline Member & Frequency & Percentage \\
\hline Occupation & & \\
\hline Managing Partner & 47 & 18.7 \\
\hline Partner & 29 & 11.6 \\
\hline Audit Supervisor & 48 & 19.1 \\
\hline Tuditor & 127 & 50.6 \\
\hline Total & 251 & 100.0 \\
\hline Academic Qualification & & \\
\hline Bachelor Degree & 195 & 77.7 \\
\hline Master Degree & 49 & 19.5 \\
\hline Ph.D. degree & 7 & 2.8 \\
\hline Total & 251 & 100.0 \\
\hline Experience as auditor & & \\
\hline Less than 3 years & 14 & 5.6 \\
\hline 3 - 5 years & 63 & 25.1 \\
\hline $6-10$ years & 83 & 33.1 \\
\hline Total & 251 & 100.0 \\
\hline More than 10 years & 91 & \\
\hline Size of audit office & & 21.5 \\
\hline Less than 3 auditors & 54 & 52.6 \\
\hline $4-10$ auditors & 132 & 25.9 \\
\hline More than 10 auditors & 65 & 100.0 \\
\hline Total & 251 & \\
\hline & & \\
\hline
\end{tabular}


In this study conducts the $\mathrm{T}$ test (Independent Samples Test) to test whether there is any statistically difference between; (1) respondents from Tripoli and Benghazi; (2) respondents gender difference; and (3) early respondents and late respondents. There is no significant difference between the groups in city, gender, and respondent. The test was conducted the ANOVA to test whether there is any statistically difference, among all of these previous categories in table 1. From the ANOVA results, it shows that there is no statistically significance at the $\mathrm{p}>.05$ for all groups.

\section{Variable measurement \\ Audit team characteristics}

Audit team characteristics consists of four dimensions which covering 18 items in this section. The adoption of each item is measured on a five-point Likert scale ranging from $1=$ strongly disagree to $5=$ strongly agree.

According to literature the independence measuring by four items which are; provision of nonaudit services (NAS), audit tenure, audit competition, and audit committees. There are several researchers see the that these elements affect the audit independence, such as; [38, 39, 40, 10, 11, 41, 42, 23, 13, 43] and Act SOX (2002).

There are five items to measure the education and training continuing professional according to Act No, 116 LAAA; Gallegos \& Carlin [44, 18, 45, 46, 24], as follow; (1) the auditors have at least a bachelor degree in accounting. (2) The auditors have professional certificates. (3) Existence of continuing professional education programs for auditors' team. (4) External auditor should achieve in the year at least 40 hours as the continuing professional education. (5) The auditor training policy includes the training programs both of inside and outside the audit team.

According to literature the experience can be measuring by the following four items [47, 14]: (1) the audit firm has been performing the audit for at least five years. (2) The audit manager has been on the audit for at least three years. (3) The audit engagement partner has been on the audit for at least two to three years. (4) The audit supervisor has been on the audit for at least two to three years.

The current study will focus on some elements for professional conduct that can measure it, based on Carcello et al. [25]; Boon et al. [48]; IESBA [24] paragraph 100.5, 150.1, 150.2. These elements are: contingent fees, gifts and hospitality, confidentiality, and family and personal relationships.

\section{The external environment audit factors}

The external environment audit consists of three dimensions which covering 14 items in this section. The adoption of each item is measured on a five-point Likert scale ranging from $1=$ strongly disagree to $5=$ strongly agree .

A few studies have been considered to the importance of professional bodies such as; [2, 27]. There are four items to measure the professional bodies; (1) the existence of strong professional body overseeing the profession. (2) Regulators provide the auditing and accounting standard issued and enforcement mechanism reliably. (3) The professional body followed up the application of guideline principles and standards from its members. (4) Regulators are quite forceful for continuing training and education requirements.

Many studies have investigated the relation between audit quality and various legal regimes, such as; [28, 29, 30, 31, 32]. According to these studies there are five items to measure the laws and regulations; (1) the existence of appropriate laws and regulations. (2) The audit team has sufficient knowledge about laws and regulations governing the profession. (3) The laws and regulations have penalties which urge on its implementation. (4) The audit team committed with laws and regulations. (5) Sanction imposed for ethics violations are strictly enforced in auditing professional.

Several studies noted the importance of recognized standards such as; [25, 27, 32]. In this paper, five items to measure the recognized standards; (1) the extent of audit team's knowledge about the international standards for auditing. (2) The audit team uses its knowledge about the international standards for auditing. (3) The audit staff assigned to the engagement has very high ethical standards. (4) Audit client's financial statements conform to generally accepted accounting principles. (5) Retain in the office of standards and regulations pertaining to the profession to return to it when needed.

\section{Audit Quality}

In order to measure audit quality, constructs of (DeAngelo [49, 14] were applied for this research. Four item follow: (1) the errors of accounting system of the audit client. (2) The material weakness of internal control system of the audit client. (3) The audit clients don't follow regulations. (4) A material fraud of audit client's financial statement. The adoption of each item is measured on a five-point Likert scale ranging from $1=$ strongly disagree to $5=$ strongly agree. 
Table-2: display the results of descriptive statistics for audit team characteristics

\begin{tabular}{|l|c|c|c|c|}
\hline Items & Mean & Std dev & Min & Max \\
\hline $\begin{array}{l}\text { External Audit Independence } \\
\text { Auditor tenure more than five years }\end{array}$ & 3.99 & 0.867 & 1 & 5 \\
\hline Existence of an audit committee in the client company & 3.96 & 0.898 & 1 & 5 \\
\hline High level of competition between the external auditors & 3.95 & 1.007 & 2 & 5 \\
\hline Non-audit services (NAS) & 3.90 & 0.717 & 1 & 5 \\
\hline $\begin{array}{l}\text { Professional Conduct } \\
\text { The auditors have at least a bachelor degree in accounting. }\end{array}$ & 3.97 & 0.899 & 1 & 5 \\
\hline The auditors have professional certificates. & 3.90 & 0.814 & 2 & 5 \\
\hline Existence of continuing professional education programs for auditors' team & 3.89 & 0.849 & 1 & 5 \\
\hline $\begin{array}{l}\text { The auditor training policy includes the training programs both of inside and } \\
\text { outside the audit team. }\end{array}$ & 3.88 & 0.803 & 1 & 5 \\
\hline $\begin{array}{l}\text { External auditor should achieve in the year at least 40 hours as the continuing } \\
\text { professional education }\end{array}$ & 3.70 & 0.922 & 1 & 5 \\
\hline $\begin{array}{l}\text { Education \& Training Continuing Professional } \\
\text { The audit firm has been performing the audit for at least five years. }\end{array}$ & 3.92 & 0.835 & 2 & 5 \\
\hline The audit supervisor has been on the audit for at least two to three years. & 3.87 & 0.774 & 2 & 5 \\
\hline The audit manager has been on the audit for at least three years. & 3.84 & 0.799 & 2 & 5 \\
\hline $\begin{array}{l}\text { The audit engagement partner has been on the audit for at least two to three } \\
\text { years. }\end{array}$ & 3.78 & 0.792 & 2 & 5 \\
\hline $\begin{array}{l}\text { Practical Experience } \\
\text { Existence of personal interests between the audit firm and its clients. }\end{array}$ & 4.06 & 0.775 & 2 & 5 \\
\hline Existence of personal interests between audit team members and auditees. & 4.02 & 0.815 & 2 & 5 \\
\hline Acceptance of gifts from the clients. & 3.96 & 0.875 & 1 & 5 \\
\hline Existence of kinship between the audit team member and the auditees. & 3.90 & 0.837 & 2 & 5 \\
\hline Contingent fees. & 3.70 & 0.896 & 2 & 5 \\
\hline
\end{tabular}

Table-3: display the results of descriptive statistics for moderating variable - Environment Audit Factors

\begin{tabular}{|l|c|c|c|c|}
\hline Items & Mean & Std dev & Min & Max \\
\hline $\begin{array}{l}\text { Professional Bodies } \\
\text { Regulators provide the auditing and accounting standard issued and } \\
\text { enforcement mechanism reliably. }\end{array}$ & 4.08 & 0.700 & 2 & 5 \\
\hline $\begin{array}{l}\text { The professional body followed up the application of guideline principles } \\
\text { and standards from its members. }\end{array}$ & 4.08 & 0.757 & 2 & 5 \\
\hline $\begin{array}{l}\text { Regulators are quite forceful for continuing training and education } \\
\text { requirements. }\end{array}$ & 3.96 & 0.787 & 2 & 5 \\
\hline The existence of effective professional body overseeing the profession. & 3.93 & 0.834 & 2 & 5 \\
\hline $\begin{array}{l}\text { Laws and Regulations } \\
\text { The laws and regulations have penalties which urge on its implementation. }\end{array}$ & 4.07 & 0.710 & 2 & 5 \\
\hline The audit team committed with laws and regulations. & 4.07 & 0.681 & 2 & 5 \\
\hline $\begin{array}{l}\text { Sanction imposed for ethics violations are strictly enforced in auditing } \\
\text { professional. }\end{array}$ & 4.04 & 0.814 & 2 & 5 \\
\hline $\begin{array}{l}\text { The audit team has sufficient knowledge about laws and regulations } \\
\text { governing the profession. }\end{array}$ & 4.04 & 0.853 & 2 & 5 \\
\hline The existence of appropriate laws and regulations. & 3.94 & 0.813 & 2 & 5 \\
\hline $\begin{array}{l}\text { Recognized Standards } \\
\text { Retain in the office of standards and regulations pertaining to the } \\
\text { profession to return to it when needed. }\end{array}$ & 4.23 & 0.677 & 2 & 5 \\
\hline The audit staff assigned to the engagement have very high ethical standards & 4.21 & 0.679 & 2 & 5 \\
\hline $\begin{array}{l}\text { Audit client's financial statements conform to generally accepted } \\
\text { accounting principles. }\end{array}$ & 4.18 & 0.625 & 2 & 5 \\
\hline $\begin{array}{l}\text { Audit team uses its knowledge about the international standards for } \\
\text { auditing. }\end{array}$ & 4.11 & 0.610 & 2 & 5 \\
\hline $\begin{array}{l}\text { The extent of audit team's knowledge about the international standards for } \\
\text { auditing. }\end{array}$ & 4.08 & 0.714 & 2 & 5 \\
\hline
\end{tabular}


Table-4: Descriptive statistics for Dependent Variable - Audit Quality

\begin{tabular}{|c|c|c|c|c|}
\hline Items & Mean & Std dev & Min & Iax \\
\hline Detects and reports the material weakness of internal control system of the audit client. & 4.00 & 0.718 & 2 & 5 \\
\hline Detects and reports a material fraud of audit client's financial statement. & 3.99 & 0.715 & 2 & 5 \\
\hline Detects and reports that the audit clients don't follow regulations. & 3.98 & 0.701 & 2 & 5 \\
\hline Detects and reports the errors of accounting system of the audit client. & 3.96 & 0.781 & 1 & 5 \\
\hline Total & 3.98 & 0.538 & 3 & 5 \\
\hline
\end{tabular}

\section{Testing goodness of data}

Reliability is considered a most important factor, being the most widely used measure. According to Hair et al. [50] reliability is an assessment of the degree of consistency between multiple measurements of variable. Ideally, the Cronbach's alpha coefficient of scale should be above $0.70[51,50]$.

Table-5: Reliability Statistics- Summary

\begin{tabular}{|c|c|c|}
\hline Variables and Dimension & Number of Item & Cronbach's Alpha \\
\hline Audit Team Characteristics & 18 & .852 \\
\hline External Audit Independence & 4 & .709 \\
\hline Professional Conduct & 5 & .759 \\
\hline Education \& Training Continuing Professional & 4 & .717 \\
\hline Practical Experience & 5 & .761 \\
\hline Environment Audit Factors & 14 & .817 \\
\hline Professional Bodies & 4 & .734 \\
\hline Laws and Regulations & 5 & .754 \\
\hline Recognized Standards & 5 & .767 \\
\hline Audit Quality & 4 & .719 \\
\hline
\end{tabular}

Table 5 summarizes the results of Cronbach's alpha which was from 0.709 to 0.852 , meaning that the constructs have good internal consistency.

Factor analysis was used to check the number dimensions conceptualized. Factor analysis is a technique of interdependence, whose main purpose is to define the underlying structure between the variables in the analysis [50]. In order to use factor analysis, the sample size should be 100 or larger and the variables must have sufficient correlations [50]. Tabachnick \& Fidell [52] finds that, values of 0.6 and above are required for good factor analysis and factor loading of values must exceed 0.5 for each question. The individual variable with measure of sampling adequacy (MSA) values below 0.50 should be considered to be omitted [50].

Table-6: Results of Eigenvalues, Percentage of Variance Explained, and MSA for All Variables and Dimension

\begin{tabular}{|c|c|c|c|}
\hline Variables and Dimension & Eigenvalue & Percentage of variance explained & MSA \\
\hline Audit Team Characteristics & 2.239 & 53.541 & 0.848 \\
\hline External Audit Independence & 2.158 & 53.955 & 0.750 \\
\hline Professional Conduct & 2.551 & 51.026 & 0.796 \\
\hline Education \& Training Continuing Professional & 2.167 & 54.172 & 0.749 \\
\hline Practical Experience & 2.562 & 51.234 & 0.791 \\
\hline Environment Audit Factors & 2.264 & 53.283 & 0.848 \\
\hline Professional Bodies & 2.238 & 55.948 & 0.758 \\
\hline Laws and Regulations & 2.529 & 50.586 & 0.794 \\
\hline Recognized Standards & 2.596 & 51.927 & 0.784 \\
\hline Audit Quality & 2.175 & 54.368 & 0.757 \\
\hline
\end{tabular}

Factor analysis for each individual dimension indicated that the items of each dimension are unidimensional as they loaded satisfactory on a single factor (from 0.707 to 0.780 ). Eigenvalues values more then 2 each dimension or variable. Overall, the MSA is above 0.70 meaning that all variables have sufficient intercorrelation and meet the requirement to conduct the factor analysis.

\section{EMPIRICAL RESULTS}

Correlation analysis and multiple regression analysis were conducted to test the relationship between audit team characteristics and environment audit factors, and audit quality. Table 7 displays the results of correlation analysis for all variables involved in the study. In general, the table shows that all variables have a positive and significant correlation at the 0.01 level with audit quality. From Table 7, the highest correlation 
Table-7: The Correlation Analysis- All Variables

\begin{tabular}{|c|c|c|c|c|c|c|c|c|}
\hline & & $(2)$ & (3) & (4) & (5) & (6) & (7) & (8) \\
\hline 1) Independence & & & & & & & & \\
\hline 2) Education \& Training & $.351^{* * *}$ & 1 & & & & & & \\
\hline 3) Experience & $.343^{* *}$ & $.467^{* *}$ & 1 & & & & & \\
\hline 4) Professional Conduct & $.404^{* *}$ & $.407^{* *}$ & $.358^{* * *}$ & 1 & & & & \\
\hline 5) $\quad$ Professional Bodies & $.348^{* *}$ & $.277^{* *}$ & $.237^{\text {** }}$ & $.255^{* *}$ & 1 & & & \\
\hline 6) Laws \& Regulations & $.175^{* *}$ & $.248^{* *}$ & $.133^{*}$ & $.293^{* *}$ & $.240^{* *}$ & 1 & & \\
\hline 7) Recognized Standards & $.388^{* *}$ & $.208^{* * *}$ & $.240^{* * *}$ & $.211^{* * *}$ & $.578^{* * *}$ & $.256^{* * *}$ & 1 & \\
\hline 8) Audit Quality & $.404^{* *}$ & $.330^{* * *}$ & $.333^{* * *}$ & $.351^{* * *}$ & $.709^{* *}$ & $.408^{* * *}$ & $.680^{* *}$ & 1 \\
\hline
\end{tabular}

Multiple regression according to, Tabachnick \& Fidell [52], is used to predict the score on the dependent variable from scores on several independent variable's. Multiple regressions are based on correlation but allow a more sophisticated exploration of the interrelationship among a set of variables [51]. This section describes the results of the hypothesis testing using regression analysis.
The results of multiple regression analysis as summarized in Table 8 show that the audit team characteristics is positively and significantly related to audit quality. The results indicate that $23 \%\left(\mathbf{R}^{2}=.230\right)$ of audit quality are explained by the independent variable. The $\mathrm{R} 2$ was statistically significant with $\mathrm{F}=$ 74.251 and $\mathrm{p}<.01$.

Table-8: The Regression Models of Audit Team Characteristics with Audit Quality

\begin{tabular}{|c|c|c|c|}
\hline Variable & Coeff. (B) & Std. Error & Beta \\
\hline Constant & 1.753 & .261 & \\
\hline Audit Team Characteristics & .572 & .066 & $.479 * * *$ \\
\hline $\mathbf{R}^{2}$ & .230 & & \\
\hline Adj. $\mathbf{R}^{2}$ & .227 & & \\
\hline F & $74.251 * * *$ & & \\
\hline Df & $(1,249)$ & & \\
\hline
\end{tabular}

*** Significant at the 0.01 level; **significant at the 0.05 level; *significant at the 0.10 level.

The regression result for each dimension of audit team characteristics i.e. independence, continuous education and training, experience and professional conduct with audit quality is displayed in Table 9. The four independent dimensions in audit quality $24 \%\left(\mathbf{R}^{2}\right.$ $=.240$ ) of variance in audit quality. Among these dimensions the external audit independence $(b=.256$, $\mathrm{p}<.01)$, the professional conduct $(\mathrm{b}=.152, \mathrm{p}<.01)$, practical experience $(b=.137, p<.01)$, and education and training continuing professional $(b=.115, \mathrm{p}<.05)$ have a unique and significant impact on audit quality respectively, and is statistically significant, F (4.246) = $19.419, \mathrm{p}<.01$.

Table-9: The Regression Models of each Dimension of Audit Team Characteristics with Audit Quality

\begin{tabular}{|l|c|c|c|}
\hline Variable & Coeff. (B) & Std. Error & Beta \\
\hline Constant & 1.733 & .261 & \\
\hline Independence & .214 & .053 & $.256^{* * *}$ \\
\hline Education \& Training & .101 & .058 & $.115^{* *}$ \\
\hline Experience & .125 & .059 & $.137^{* * *}$ \\
\hline Professional Conduct & .136 & .058 & $.152^{* * *}$ \\
\hline $\mathbf{R}^{2}$ & .240 & & \\
\hline Adj. $\mathbf{R}^{2}$ & .228 & & \\
\hline F & $19.419 * * *$ & & \\
\hline Df & $(4,246)$ & & \\
\hline
\end{tabular}

*** Significant at the 0.01 level; **significant at the 0.05 level; *significant at the 0.10 level.

In this study the results of hierarchical multiple regression examined the direct and indirect effect of moderating variable. Moderating according to Bennet [53] is an independent variable that affects the strength and direction of the association among dependent variable or another independent variable. Hierarchical multiple regression has been introduced variables according to the steps proposed by Pallant [51]. 
As displayed in Table 10, the results support hypothesis 2 that the external environment of audit moderate the relationship between audit team and audit quality. The $\mathrm{R}$ square of the models changed with the interaction of moderator (from $\mathbf{R}^{2}=.635$ to .640). The interaction coefficient (standardized beta) of the external environment audit factors is significant $\left(\mathbf{R}^{2}\right.$ change $=.005, b=1.115 ; \mathrm{p}<0.10)$. The results suggest that the environment audit factors have significant and effect in moderating the relationship between audit team and audit quality.

From the analysis, the results support $\mathrm{H} 2 \mathrm{a}$ that the moderation effect is significant for the audit team characteristics and audit quality, and each dimension of environment audit factors i.e. professional bodies, laws and regulations, and recognized standards (refer Table 11, Table 12, and Table 13).

Table-10: Results of hierarchical regression analyses for main and moderation effect: the external environment audit factors of moderates the relationship between audit team and audit quality

\begin{tabular}{|c|c|c|c|c|c|c|}
\hline Model & \multicolumn{3}{|c|}{1} & \multicolumn{3}{|c|}{2} \\
\hline DV & \multicolumn{3}{|c|}{ Audit Quality } & \multicolumn{3}{|c|}{ Audit Quality } \\
\hline Variable & Coeff. (B) & Std. Error & Beta & Coeff. (B) & Std. Error & Beta \\
\hline Constant & -.695 & .233 & & 2.555 & 1.749 & \\
\hline Main Effect audit team & .189 & .051 & $.158 * * *$ & -.651 & .451 & -.545 \\
\hline external environment Moderator & .968 & .058 & $.713 * * *$ & .152 & .439 & .112 \\
\hline audit team * external environment & & & & .210 & .112 & $1.115 *$ \\
\hline $\mathbf{R}^{2}$ & .635 & & & .640 & & \\
\hline Adj. $\mathbf{R}^{2}$ & .632 & & & .635 & & \\
\hline Change in $\mathbf{R}^{2}$ & .635 & & & .005 & & \\
\hline $\mathrm{F}$ & $215.458 * * *$ & & & $146.268 * * *$ & & \\
\hline F change & $215.458 * * *$ & & & $3.516^{* *}$ & & \\
\hline Df & $(2,248)$ & & & $(3,247)$ & & \\
\hline
\end{tabular}

$* * *$ Significant at the 0.01 level; **significant at the 0.05 level; *significant at the 0.10 level.

As shown in Table 11, professional bodies moderate the relationship between audit team and audit quality. The $\mathbf{R}^{2}$ audit quality and audit team slightly increased from 0.555 without interaction to 0.563 with the interaction of moderator. The interaction coefficient (standardized beta) is significant; $\left(\mathbf{R}^{2}\right.$ change $=.008$, $\mathrm{b}=1.160, \mathrm{p}<0.05)$.

Table-11: Results of hierarchical regression analyses for main and moderation effect: the professional bodies of moderates the relationship between audit team and audit quality

\begin{tabular}{|c|c|c|c|c|c|c|}
\hline Model & \multicolumn{3}{|c|}{1} & \multicolumn{3}{|c|}{2} \\
\hline DV & \multicolumn{3}{|c|}{ Audit Quality } & \multicolumn{3}{|c|}{ Audit Quality } \\
\hline Variable & Coeff. (B) & Std. Error & Beta & Coeff. (B) & $\begin{array}{l}\text { Std. } \\
\text { Error }\end{array}$ & Beta \\
\hline Constant & .523 & .218 & & 3.364 & 1.362 & \\
\hline Main Effect Audit Team & .294 & .055 & $.246 * * *$ & -.440 & .351 & -.368 \\
\hline Bodies Moderator & .576 & .043 & $.616^{* * *}$ & -.148 & .345 & -.158 \\
\hline Audit Team * Bodies & & & & .186 & .088 & $1.160 * *$ \\
\hline $\mathbf{R}^{2}$ & .555 & & & .563 & & \\
\hline Adj. $\mathbf{R}^{2}$ & .552 & & & .558 & & \\
\hline Change in $\mathbf{R}^{2}$ & .555 & & & .008 & & \\
\hline $\mathrm{F}$ & $154.871 * * *$ & & & $106.177 * * *$ & & \\
\hline F change & $154.871 * * *$ & & & $4.464 * * *$ & & \\
\hline Df & $(2.248)$ & & & $(3.247)$ & & \\
\hline
\end{tabular}

*** Significant at the 0.01 level; **significant at the 0.05 level; *significant at the 0.10 level.

Table 12 highlights for laws and regulations moderate the relationship between audit team and audit quality. The moderation effect of laws and regulations are significant $\left(\mathbf{R}^{2}\right.$ change $\left.=.010, b=-1.296, \mathrm{p}<0.10\right)$ in the relationship of audit team and audit quality. The $\mathbf{R}^{2}$ is 0.317 and adds 1.00 percent to explanatory power to explain the variance in audit quality. 
Table-12: Results of hierarchical regression analyses for main and moderation effect: the laws and regulations of moderate the relationship between audit team and audit quality

\begin{tabular}{|l|c|c|c|c|c|c|}
\hline \multicolumn{1}{|c|}{ Model } & \multicolumn{3}{c|}{ 1 } & \multicolumn{3}{c|}{ 2 } \\
\hline \multicolumn{1}{|c|}{ DV } & \multicolumn{3}{c|}{ Audit Quality Quality } \\
\hline Variable & Coeff. (B) & Std. Error & Beta & Coeff. (B) & Std. Error & Beta \\
\hline Constant & .977 & .288 & & 4.386 & 1.798 & \\
\hline Main Effect audit team & .469 & .066 & $.393^{* * *}$ & -.423 & .469 & -.354 \\
\hline laws \& regulations Moderator & .292 & .055 & $.292^{* * *}$ & -.565 & .450 & -.564 \\
\hline audit team * laws \& regulations & & & & .223 & .116 & $1.296^{*}$ \\
\hline $\mathbf{R}^{2}$ & .307 & & & .317 & & \\
\hline Adj. $\mathbf{R}^{2}$ & .302 & & & .309 & & \\
\hline Change in $\mathbf{R}^{2}$ & .307 & & & .010 & & \\
\hline F & $55.001^{* * *}$ & & & $38.294^{* * *}$ & & \\
\hline F change & $55.001^{* * *}$ & & & $3.688^{* *}$ & & \\
\hline Df & $(2.248)$ & & & $3.247)$ & & \\
\hline
\end{tabular}

*** Significant at the 0.01 level; **significant at the 0.05 level; *significant at the 0.10 level.

Table 13 highlights for recognized standards moderate the relationship between audit team and audit quality. The moderation effect of recognized standards is significant $\left(\mathbf{R}^{2}\right.$ change $\left.=.010, \mathrm{~b}=-1.291 ; \mathrm{p}<0.05\right)$ in the relationship of audit team and audit quality. The $\mathbf{R}^{2}$ is 0.537 and adds 0.80 percent to explanatory power to explain the variance in audit quality.

Table-13: Results of hierarchical regression analyses for main and moderation effect: the recognized standards of moderate the relationship between audit team and audit quality

\begin{tabular}{|c|c|c|c|c|c|c|}
\hline Model & \multicolumn{3}{|c|}{1} & \multicolumn{3}{|c|}{2} \\
\hline DV & \multicolumn{3}{|c|}{ Audit Quality } & \multicolumn{3}{|c|}{ Audit Quality } \\
\hline Variable & Coeff. (B) & Std. Error & Beta & Coeff. (B) & Std. Error & Beta \\
\hline Constant & -.040 & .249 & & 3.536 & 1.717 & \\
\hline Main Effect audit team & .329 & .055 & $.275 * * *$ & -.614 & .451 & -.515 \\
\hline standards Moderator & .659 & .052 & $.584 * * *$ & -.218 & .420 & -.194 \\
\hline audit team * standards & & & & .230 & .109 & $1.291 * *$ \\
\hline $\mathbf{R}^{2}$ & .529 & & & .537 & & \\
\hline Adj. $\mathbf{R}^{2}$ & .525 & & & .532 & & \\
\hline Change in $\mathbf{R}^{2}$ & .529 & & & .008 & & \\
\hline $\mathrm{F}$ & $139.257 * * *$ & & & $95.599 * * *$ & & \\
\hline F change & $139.257 * * *$ & & & $4.430 * * *$ & & \\
\hline Df & $(2.248)$ & & & $(3.247)$ & & \\
\hline
\end{tabular}

\section{DiSCUSSION OF FINDINGS}

The results show that audit team characteristics, which consists of independence, education and continuous professional training, practical experience and professional conduct, has a significant relationship with audit quality (Table 8). It is predicted that auditor commitment of the audit team characteristics will effectively reflect higher audit quality. In terms of correlations (Table 7), the association between audit team characteristics and audit quality are positive with medium significance. Thus, audit team characteristics can be explained via its relation to audit quality. This is in line with the suggestions in prior literature, such as, Aldhizer et al., [6], Wooten [9], Cheng et al., [7], which claimed that educational attainment of auditors, continuous professional development, their practical experience, and professional certification can enhance auditor quality. Wooten [9] suggested that audit team characteristics were more important than firm-wide factors in determining audit quality. According to the FRC [54], the personal qualities of audit partners, skills, the education, and the training given to audit personnel, are important factors that determine auditor quality. Audits require the auditors to have a degree of higher education and professional development, reasonable experience and knowledge concerning the rules of professional conduct as well as full independence to carry out high audit quality.

A significant positive relationship exists between external audit's independence and audit quality (Table 9). Results indicate whenever the auditor has a greater degree of independence this will effectively reflect greater audit quality. This is in line with the 
suggestions in prior literature, such as, Dee, et al., [5], Sucher \& Maclullich [56], Chen et al. [11], Sori \& Karbhari [41], Wong [15]. Baotham \& Ussahawanitchakit [14] and Mansouri et al. [16] find a significant positive relationship between external audit's independence and audit quality.

Continuous professional education and training are one of the basic pillars that ensure that the competent authorities and rehabilitation necessary to meet the requirements of performing the audit function and achieving audit quality are present. Specifically, results show that greater education and training effectively reflect higher audit quality. Education and training dimension shows a positive and significant relationship with audit quality (Table 9). Several studies found that educational and professional level relates positively to audit quality; for instance, Meinhardt et al., Deis and Giroux [17], Shoommuangpak [18], and Cheng et al. [7]. These studies assert that audit quality is influenced by continuing professional education and training.

The results indicate that practical experience has a significant positive effect on audit quality (Table 9). The results provide support for various claims in the literature that high practical experience enhances the performance of external audit function that will lead to enhanced audit quality. The higher practical experience for external auditors make fewer concessions in high risk auditor-client negotiations if faced with a client who prefers an aggressive financial reporting position as compared with low experience auditors $[21,18]$. The high practical experiences of auditors are more wary of a number of potential errors, and are more capable of discovering weaknesses and accounting errors [19, 20].

The results show that professional conduct for auditors has a significant positive relationship with audit quality (Table 9). The audit quality is an outcome of high professional conduct. Audit quality is associated with professional conduct in a way that events positively affecting professional conduct support the financial statement audited. Most current lawsuits against auditing firms allege unethical behavior on the part of auditors [57]. According to IESBA [24], stated in paragraph 100.5 , professional auditors' shall comply with the following relevant ethical requirements: integrity, objectivity, professional competence and due care, and confidentiality. The principle of professional conduct imposes an obligation upon the auditors to comply with relevant laws and avoidance of any conduct or any action that the auditors know may discredit the profession of auditors' work [24].

The external environment factors of audit moderate the relationship among audit team characteristics, and audit quality. The external environment factors are important for the audit team characteristics because they regulate, issue and oversee the work of the auditors through standards, laws and regulations, and professional bodies that underpin the audit quality. The results indicate that the interaction coefficient (standardized beta) of the external environment audit factors is significant (Table 10), and thus it can help to enhance audit quality. The results of descriptive analysis found that external environment factors of audit have a higher mean score compared to other variables (see Table 3). It is certain that the factors of external environment surrounding the audit office affect the audit quality, the audit team characteristics.

The aim of these professional bodies is the development and enhancement of a coordinated worldwide accountancy profession with harmonized standards. Professional bodies have contributed, to national or international accounting, in the regulation and supervision of the profession. Generally, professional body moderates the relationship between audit team and audit quality. The results show that professional bodies moderates, in a significant and positive way, the relationship between audit team and audit quality (Table 11). Therefore, the professional bodies should consider mandating the use of auditing standards to remove any ambiguity and improvement the audit quality [58]. Few studies have considered the importance of professional bodies [2, 27].

Laws and regulations strongly affect the practice of the audit profession because they are legally binding. Laws and regulations moderate the relationship between audit team and audit quality. The results show that the moderating effect of laws and regulations are significant in the relationship of audit team and audit quality (Table 12). There are many studies that investigated the relation between audit quality and various legal regimes[28, 2, 31, 32]. Hillegeist [30] points out that the legal regime leads to the highest level of audit quality will always lead to the lowest failure rate. Most current lawsuits against auditing firms alleged unethical behavior on the part of auditors, and declining public trust in the auditing profession [57]. It is clear how important the existence of laws and regulations are to keep up with the changes taking place in the world to improve the quality of auditing and the audit team characteristics.

Recognized standards moderate the relationship between audit team and audit quality. The results show that the moderation effect of recognized standards are significant in the relationship of audit team and audit quality (Table 13). This is in line with the suggestions in prior literature and standards, for example, there is a close link between recognized standards and auditor independence. Similarly, IFAC [33] ISQC 1 provided the paragraphs (21 to 25) particularly for independence requirements. According to standard No (IES 7) (2006) by IAESB, the types of learning activities constitute continuing professional 
development of auditors. IFAC [33] indicates that auditors must have practical audit experience, and a reasonable understanding of audit processes, applicable legal and regulatory requirements. The descriptive statistics results (see Table 3) show that recognized standards have a higher mean score compared to other dimensions. This could offer an explanation that the recognized standards moderate the significant relationship between audit team and audit quality. The opinions above are consistent with the suggestion by Colbert, et al. [27, 59] where the criteria include college educational requirements, work experience, and continuing professional education. Our results suggest that applying IAS is associated with improvement in accounting quality.

The results suggest that audit team characteristics are able to enhance the audit quality and that the relationship becomes stronger if there are external environment factors of the professional body in the form of laws and regulations, and recognized standards.

\section{Contributions ANd FUture \\ RESEARCH}

\section{Future directions}

Firstly, the study could be replicated to include the opinions of people in different industrial sectors in an attempt to gain a wider picture of the perception of audit quality, and the factors influencing it.

Secondly, the study could be replicated in advanced countries to determine whether these factors affect audit quality, particularly the Big 4 firms and a comparison of the results can be conducted to see whether there are differences between small and big firms and to establish whether cultural influences in different countries influence perceptions of audit quality. Such a study might highlight the existence of new and additional factors that might come into play.

- Third, future research can extend this model by looking at office factors' impact upon audit quality.

- Finally, the proposed model can be tested by applying this model to measure audit quality of practice.

\section{CONCLUSION}

The study found that the adoption of multidimensional audit team characteristics that consist of independence, education and training, experience, and professional conduct is positively and significantly related to audit quality. The results show that auditor commitment to the audit team characteristics effectively reflects high audit quality. The results are consistent with past literature claiming that the measures in the audit team characteristics are important measures that can be critical factors of audit quality enhancement. The organizations can use these multi-dimensional measures to measure audit quality.

The external environment factors are important for the audit team characteristics because they regulate, issue and oversee the work of the auditors through standards, laws and regulations, and professional bodies that underpin audit quality. The results indicate that the interaction coefficient of the external environment audit factors is significant and thus it can help enhance audit quality. The results suggest that audit team is able to enhance audit quality, and that the relationship becomes stronger if there is external environment factors of audit.

\section{REFERENCES}

1. Sutton, S. G. (1993). Toward an understanding of the factors affecting the quality of the audit process. Decision Sciences, 24(1), 88-105.

2. Grant, J., Bricker, R., \& Shiptsova, R. (1996). Audit quality and professional self-regulation: A social dilemma perspective and laboratory investigation. Auditing, 15(1), 142.

3. Reisch, J.T. (2000). "Ideas for Future Research on Audit Quality", The Audit Report, 24(1), Fall.

4. Ghany, K. A. (2012). Dogovernment Audits. Journal of Government Financial Management.

5. King, R. R. (2002). An experimental investigation of self-serving biases in an auditing trust game: The effect of group affiliation. The Accounting Review, 77(2), 265-284.

6. Aldhizer III, G. R., Miller, J. R., \& Moraglio, J. F. (1995). Common attributes of quality audits. Journal of Accountancy, 179(1), 61.

7. Cheng, Y. S., Liu, Y. P., \& Chien, C. Y. (2009). The association between auditor quality and human capital. Managerial Auditing Journal.

8. Catanach Jr, A. H., \& Walker, P. L. (1999). The international debate over mandatory auditor rotation: A conceptual research framework. Journal of International Accounting, Auditing and Taxation, 8(1), 43-66.

9. Wooten, T. C. (2003). Research about audit quality. The CPA Journal, 73(1), 48.

10. Bakar, N. B. A., Rahman, A. R. A., \& Rashid, H. M. A. (2005). Factors influencing auditor independence: Malaysian loan officers' perceptions. Managerial Auditing Journal.

11. Chen, K. Y., Elder, R. J., \& Liu, J. L. (2005). Auditor independence, audit quality and auditorclient negotiation outcomes: some evidence from Taiwan. Journal of Contemporary Accounting \& Economics, 1(2), 119-146.

12. Salehi, M., Mansoury, A., \& Azary, Z. (2009). Audit independence and expectation gap: Empirical evidences from Iran. International Journal of Economics and Finance, 1(1), 165-174.

13. Bakar, N. B. A., \& Ahmad, M. (2009). Auditor independence: Malaysian accountant's 
perception. International journal of business and management, 4(12), 129-141.

14. Baotham, S., \& Ussahawanitchakit, P. (2009). Audit independence, quality, and credibility: effects on reputation and sustainable success of CPAs in Thailand. International Journal of Business Research, 9(1), 1-25.

15. Wong, N. (2005). Determinants of the accounting change for income tax. Journal of Business Finance \& Accounting, 32(5-6), 1171-1196.

16. Mansouri, A., Pirayesh, R., \& Salehi, M. (2009). Audit competence and audit quality: Case in emerging economy. International Journal of Business and Management, 4(2), 17-25.

17. Deis Jr, D. R., \& Giroux, G. A. (1992). Determinants of audit quality in the public sector. Accounting Review, 462-479.

18. Shoommuangpak, P. (2007). Auditor Expertise, Audit Quality and Client Acceptance. International Journal of Business Research, 7(1), 181-187.

19. Libby, R., \& Frederick, D. M. (1990). Experience and the ability to explain audit findings. Journal of Accounting Research, 28(2), 348-367.

20. Choo, F., \& Trotman, K. T. (1991). The relationship between knowledge structure and judgments for experienced and inexperienced auditors. Accounting Review, 464-485.

21. Brown, H. L. (2003). The effects of engagement risk and experience in auditor-client negotiations. Working Paper, University of Wisconsin-Madison.

22. Bedard, J. (1991). Expertise and its relation to audit decision quality. Contemporary Accounting Research, 8(1), 198-222.

23. Markelevich, A. J., Hoitash, R., \& Barragato, C. A. (2005). Auditor fees, abnormal fees and audit quality before and after the Sarbanes-Oxley Act. Abnormal Fees and Audit Quality Before and after the Sarbanes-Oxley Act (February 7, 2005).

24. IAESB. (2009). "Handbook of International Education Pronouncements", Available from; http://www.ifac.org.

25. Carcello, J. V., Hermanson, R. H., \& McGrath, N. T. (1992). Audit quality attributes: The perceptions of audit partners, preparers, and financial statement users. Auditing, 11(1), 1.

26. DeFond, M. L. (1992). The association between changes in client firm agency costs and auditor switching. Auditing, 11(1), 16.

27. Colbert, G., \& Murray, D. (1999). State accountancy regulations, audit firm size, and auditor quality: An empirical investigation. Journal of Regulatory Economics, 16(3), 267-286.

28. Narayanan, V.G. (1994)." An Analysis of Auditor Liability Rules", Journal of Accounting Research, 32, 39-50

29. Schwartz, R. (1997). "Legal regimes, audit quality and investment ", The Accounting ReviewVol. 72(3), 385-406.
30. Hillegeist, S.A. (1999). "Financial reporting and auditing under alternative damage apportionment rules ", The Accounting Review, 74(3), 347-369.

31. Leong, L., Huang, S.Y., \& Hsu, J. (2003). "An empirical study on professional commitment, organizational commitment and job involvement in Canadian accounting firms", Journal of American Academy of Business, 2(2), 360-70.

32. Barth, M.E, Landsman, W.R \& Lang, M.H. (2006). "International Accounting Standards and Accounting Quality", Journal of Accounting Research, 46(3), 467-498.

33. IFAC. (2010). "Handbook of International Quality Control, Auditing, Review, Other Assurance, and Related Services Pronouncements" Part I, Available from; http://www.ifac.org.

34. Sekaran, U. (2003). "Research methods for business: a skill building approach", Fourth Edition, Wiley. SILVERMAN, D. (2000) Doing Qualitative Research.

35. Darraji, A. M. (1998). "Assess the quality of audit offices in Libyan", a MSC Thesis, (Libya: The Economy College at Garyounis University).

36. Sawan, N. (2010)." An Investigation into the Perception of Oil Companies and Audit Firms on Factors Affecting Service Quality of Auditing", A Ph.D. Thesis, Liverpool John Moores University, Business School, U.K.

37. Khorwatt, E. (2006)." The Attitude of Libyan Auditors to Inherent and Control Risk Assessments". A Ph.D. Thesis, The Manchester Metropolitan University, Department of Business and Management Studies, U.K.

38. Beattie, V., Brandt, R., \& Fearnley, S. (1999). "'Perceptions of Auditor Independence: UK Evidence", Journal of International Accounting, Auditing and Taxation, 8(1), 67-107.

39. De Fond, M. L., Raghunandan, K., \& Subramanyam, K. R. (2002). "Do non-audit service fees impair auditor independence?", Evidence from going concern audit opinions. Journal of Accounting Research, 40(4), 1247-1274.

40. George, N. (2004). "Auditor Rotation and the Quality of Audits" The CPA Journal. New York, 74,. 12; 22, 4.

41. Sori, Z.M., \& Karbhari, Y. (2005). "Auditor Appointment, Rotation and Independence: Some Evidence from Malaysia ", Working Paper Series, Centre of Excellence for Applied Financial and Accounting Studies and Cardiff Business School, University Putra Malaysia.

42. Quick, R., \& Rasmussen, W. (2005). "The Impact of MAS on Perceived Auditor Independence Some Evidence from Denmark", Accounting Forum, 9, 137-168.

43. Stringer, A., \& Adamidis, A. (2010). " A guide to audit quality", Publications of Institute of Chartered Accountants in Australia, Charter I April, 64-66. 
44. Gallegos, F., \& Carlin, A. (2004). "Best Practices in Due Professional Care: An it Audit Perspective", 31 (8), 1-13.

45. IAESB. (2006). "Continuing Professional Development: A Program of Lifelong Learning and Continuing Development of Professional Competence", IES 7, pp. 82-94, Available at: http://web.ifac.org/publications/internationalaccounting-education-standardsboard/handbook\#handbook-of-international-e

46. CAQ. (2009). "Guide to Public Company Auditing", Electronic copy available at: http://www.thecaq.org.

47. Baotham, S. (2007). "Effects of Professionalism on Audit Quality and Self-Image of CPAs in Thailand", International Journal of Business Strategy, 6(2): 41-47.

48. Boon, K., McKinnon, J. and Ross, P. (2008). Audit service quality in compulsory audit tendering, Accounting Research Journal, 21(2),93-122.

49. DeAngelo, L.E. (1981). "Auditor size and audit quality", Journal of Accounting and Economics, 3, 183-199.

50. Hair, J.F., W.C. Black, B.J. Babin., \& Anderson, R.E. (2010). "Multivariate data analysis", (7th ed.), Pearson Prentice Hall: Upper Saddle River, New Jersey.

51. Pallant, J. (2005). " SPSS Survival Manual", Australia: Allen \& Unwin.
52. Tabachnick, B. G., \& Fidell, L. S. (2007). "Using Multivariate Analysis (5 th ed), Boston: Pearson Education, Inc.

53. Bennet, J.A. (2000). " Focus on Research Methods Mediator and Moderator Variables in Nursing Research: Conceptual and Statistical Differences", Research in Nursing \& Health, 23, 415-420

54. FRC. (2006). "Promoting audit quality", discussion paper, Financial Reporting Council, London, November. Available http://www.frc.org.uk/press/pub1201.html

55. Dee, C.C, Lulseged, A., \& Nowlin, T.S. (2002). "Earnings Quality and Auditor Independence: An Examination Using Non-audit Fee Data", Working Paper. Tallahassee: Florida State University, Available from; http://papers.ssrn.com/sol3/papers.cfm?abstract_id $=304185$.

56. Sucher, P \& Mmaclullich, K. (2004). "A Construction of Auditor Independence in The Czech Republic: Local Insight", Accounting, Auditing \& Accountability Journal, 17(2), 276-305.

57. Becker, T., Kipke, D., \& McDougall, C. (2005). U.S. Patent Application No. 10/738,317.

58. Marchesi, M. F. (2000). "Audit Quality in ASEAN", the International Journal of Accounting, 35(1), 121-149.

59. Krell, E. (2007). Finance and accounting outsourcing-making an informed decision. $C M A$ MANAGEMENT, 81(7), 38. 